\title{
Biological characterization of non-steroidal progestins from botanicals used for women's health
}

\author{
MF Toh ${ }^{1}$, J Sohn ${ }^{1}$, SN Chen ${ }^{1}$, P Yao ${ }^{1}$, JL Bolton ${ }^{1}$, and JE Burdette ${ }^{1}$ \\ ${ }^{1}$ Medicinal Chemistry and Pharmacognosy, University of Illinois at Chicago, Chicago, IL 60607, \\ USA
}

\section{Abstract}

Progesterone plays a central role in women's reproductive health. Synthetic progestins, such as medroxyprogesterone acetate (MPA) are often used in hormone replacement therapy (HRT), oral contraceptives, and for the treatment of endometriosis and infertility. Although MPA is clinically effective, it also promiscuously binds to androgen and glucocorticoid receptors (AR/GR) leading to many undesirable side effects including cardiovascular diseases and breast cancers. Therefore, identifying alternative progestins is clinically significant. The purpose of this study was to biologically characterize non-steroidal progestins from botanicals by investigating their interaction and activation of progesterone receptor (PR). Eight botanicals commonly used to alleviate menopausal symptoms were investigated to determine if they contain progestins using a progesterone responsive element (PRE) luciferase reporter assay and a PR polarization competitive binding assay. Red clover extract stimulated PRE-luciferase and bound to PR. A library of purified compounds previously isolated from red clover was screened using the luciferase reporter assay. Kaempferol identified in red clover and a structurally similar flavonoid, apigenin, bound to PR and induced progestegenic activity and P4 regulated genes in breast epithelial cells and human endometrial stromal cells (HESC). Kaempferol and apigenin demonstrated higher progestegenic potency in the HESC compared to breast epithelial cells. Furthermore, phytoprogestins were able to activate P4 signaling in breast epithelial cells without downregulating PR expression. These data suggest that botanical extracts used for women's health may contain compounds capable of activating progesterone receptor signaling.

\section{Keywords}

Progesterone receptor; Red clover; Flavonoid; Kaempferol; Apigenin; Naringenin

\section{Introduction}

Progesterone $\left(\mathrm{P}_{4}\right)$ is a female sex steroid that plays an essential role in normal human reproductive function in the uterus, ovary, mammary gland, and brain [1]. $\mathrm{P}_{4}$ is also implicated in non-reproductive tissues including the cardiovascular system, bone, and central nervous system stressing the importance and prevalence of this hormone in normal

(C) 2012 Elsevier Inc. All rights reserved.

Corresponding author and reprint request: Joanna E. Burdette, Ph.D., Assistant Professor, Department of Medicinal Chemistry and Pharmacognosy, University of Illinois at Chicago, 900 S. Ashland (M/C 870), Chicago, IL 60607, Tel: 312-996-6153, Fax: 312-996-7107, joannab@uic.edu.

Publisher's Disclaimer: This is a PDF file of an unedited manuscript that has been accepted for publication. As a service to our customers we are providing this early version of the manuscript. The manuscript will undergo copyediting, typesetting, and review of the resulting proof before it is published in its final citable form. Please note that during the production process errors may be discovered which could affect the content, and all legal disclaimers that apply to the journal pertain. 
physiology [1]. $\mathrm{P}_{4}$ mediates its actions by binding to its nuclear progesterone receptor (PR), which functions as a transcription factor to regulate downstream target genes [2]. Alternative splicing of the PR mRNA results in two distinct isoforms; the full length PRB and Nterminus truncated PRA [2]. PRA and PRB have identical DNA and ligand binding domains; however, they elicit distinct transcriptional regulatory activities [3]. For instance, in the rodent PRB mediates the proliferative effects of $\mathrm{P}_{4}$ in the mammary gland and PRA is essential for the functional response of $\mathrm{P}_{4}$ in the uterus and ovaries [1, 4]. Progesterone may also bind to progesterone receptor membrane component 1 (PGRMC1) and inhibit apoptosis in granulosa cells to maintain their viability during follicular development [5].

Progestins are essential and ubiquitous as a drug therapy in women's health. For example, endometriosis is the most common cause of infertility and chronic pelvic pain that affects 1 in 10 women of reproductive age [6]. High levels of estrogen are a well-established risk factor for endometriosis and because progesterone inhibits estrogen-driven endometrial hyperplasia, the synthetic progestin medroxyprogesterone acetate (MPA) is often used in the treatment of endometriosis and endometrial cancer [7]. Progestins are also a component of hormone replacement therapy (HRT), which is used for the alleviation of menopausal symptoms [8]. The replacement of estrogen alone increases the risk of endometrial cancer by $120 \%$ for every 5 years of use [8]. Therefore, women taking HRT must take a combination of estrogen and progestins to oppose estrogen induced uterine hyperplasia and cancer [8]. In addition, there are more than 40 million women using oral contraceptives containing progestins, which can protect against ovarian cancer but may increase the risk for blood clots $[9,10]$. While all of these conditions involve the use of a progestin, synthetic progestins are associated with deleterious side effects including blood clots, cardiovascular disease, heart attack, stroke, venothrombolic events and breast cancer primarily due to the promiscuous binding of progestins to glucocorticoid (GR) and androgen receptors (AR) (7). Therefore, the identification of alternative progestins is clinically significant. Selective PR modulators (SPRMs) are a class of PR ligands with clinically relevant tissue-selective $\mathrm{P}_{4}$ agonist and antagonist, or mixed agonist/antagonist properties [11]. Since SPRMs have the potential to provide the beneficial effects of progestins in the uterus while avoiding their drawbacks in the breast, pharmaceutical companies are currently developing non-steroidal progestins with the purpose of generating SPRMs.

Due to the side effects associated with hormone therapy and the perceived safety of natural remedies, millions of menopausal women are seeking alternatives in the form of botanical extracts and dietary supplements. Unfortunately, the use of botanicals containing only plantderived estrogens in the absence of progestin-like molecules might increase the risk of developing endometrial cancer similar to taking estrogen alone ( 7 ). For instance, red clover, hops, and angelica are common botanicals which contain phytoestrogens that bind and activate estrogen receptors and are used for the treatment of menopausal symptoms [12]. Interestingly, when hops and red clover were given orally to ovariectomized rats, uterine weights were not significantly increased in animals treated with a crude extracts as compared to pure estrogenic compounds alone, suggesting the presence of progestins capable of opposing estrogen activity [13, 14].

The purpose of this study was to identify if botanical dietary supplements currently being used for women's health contain compounds with $\mathrm{P}_{4}$-like activity. The following representative botanicals currently being sold as components of women's health formulations were tested as $75 \%$ ethanolic extracts: red clover, hops, angelica, black cohosh, kudzu, dogwood, and chaste-tree berry. Extracts were investigated for their ability to interact with purified PR, to activate PRE-luciferase transcription in T47D breast cancer cells, and for tissue specific regulation of $\mathrm{P}_{4}$ inducible genes. Red clover, kaempferol, naringenin, and 
apigenin were identified as having $\mathrm{P}_{4}$ - like activity and may function as non-steroidal SPRMs.

\section{Materials and Methods}

Reagents

All chemicals and reagents were purchased from Fisher (Hanover Park, IL) or SigmaAldrich (St. Louis, MO) unless otherwise indicated. All media for cell culture was purchased from (Life Technologies, Inc. Carlsbad, CA). Fetal bovine serum (FBS) and charcoal stripped serum was purchased from Atlanta Biologicals (Norcross, GA). Genistein, daidzein, biochanin A, formononetin, kaempferol, naringenin, apigenin (Supplementary material; Table 1) were purchased form Indofine Chemical Co. (Belle Mead, NJ) and Sigma- Aldrich (St. Louis, MO).

\section{Extraction of plant extracts}

All extracts were kindly prepared by the UIC/NIH Center for Botanical Dietary Supplements Research. Angelica sinensis (roots) was purchased from Yin Wall City, Inc. Chicago, IL (2001). Pueraria lobata (kudzu- flowering parts) was collected in Evanston, IL. Cimicifuga racemosa (black cohosh-rhizomes and roots), Cornus officinalis (dogwoodfruits), Valeriana officinalis (valerian-roots), and Vitex agnus-castus (chaste-tree berryberries), were provided by PureWorld Botanicals, now known as NATUREX (South Hackensack, NJ). A previously described $\mathrm{CO}_{2}$-extracted nugget cultivar of Humulus lupulus (hops) was provided by Yakima Chief, Inc. Sunnyside WA [15]. A Trifolium pratense (red clover) $30 \%$ isoflavones extract was provided by NATUREX (Hackensack, NJ). All voucher specimens have been deposited at the Pharmacognosy Field Station, Department of Medicinal Chemistry and Pharmacognosy, College of Pharmacy, University of Illinois at Chicago. All plant extracts were prepared as described previously [12].

\section{Cell culture and cell lines}

Human breast cancer cell line T47D American Type Culture Collection (Manassas, VA) was maintained in phenol red free RPMI 1640 medium (Life Technologies, Inc. Carlsbad, CA) containing penicillin/streptomycin $(0.1 \mathrm{mg} / \mathrm{ml}), 10 \%(\mathrm{v} / \mathrm{v})$ fetal bovine serum $(\mathrm{FBS})$ (Life Technologies, Inc. Carlsbad, CA) and $4.5 \mathrm{~g} / \mathrm{L}$ glucose. An immortalized human endometrial stromal cell line (HESC), established by Krikun et al. [16], was kindly provided by Dr. Asgi Fazleabas of University of Illinois at Chicago (Department of Obstetrics, Gynecology, and Reproductive Biology, Michigan State University, Grand Rapids, MI). HESC were cultured in DMEM/F12 1:1 (Life Technologies, Inc. Carlsbad, CA) supplemented with 10\% dextran charcoal stripped FBS (Life Technologies, Inc. Carlsbad, CA) and 1\% penicillin/ streptomycin.

\section{Luciferase assay}

T47D cells were grown in phenol-red free RPMI media in 24 well plates at 50,000 cells per well and endometrial stromal cells were grown in DMEM/F12 in 12 well plates until 80\% confluent. Plasmid containing progesterone responsive element (PRE) fused to firefly luciferase obtained from Dr. Ken Korach, (NIEHS, NIH, Research Triangle, NC) [17] was transfected into T47D cells $(0.1 \mu \mathrm{g} /$ well $)$ and HSEC $(0.5 \mu \mathrm{g} / \mathrm{well})$ using Lipofectamine 2000 (Life Technologies, Inc. Carlsbad, CA) in Opti-MEM according to the manufacturer's protocol (Life Technologies, Inc. Carlsbad, CA). PRE-luciferase transfection efficiencies were normalized to an independent control plasmid expressing beta-galactosidase ( $\beta$-gal) or renilla luciferase $(0.1 \mu \mathrm{g}$ or $0.5 \mu \mathrm{g})$, a kind gift of Dr. William T. Beck, (University of Illinois, Chicago, IL), cotransfected simultaneously. After transfection for $24 \mathrm{~h}$ or $4 \mathrm{~h}$, cells 
were treated with phytoprogestins for $24 \mathrm{~h}$ or $48 \mathrm{~h}$. Cell lysates $(50 \mu \mathrm{L})$ were aliquoted into 96 well plates. The luciferase activity in assay buffer ( $25 \mathrm{mM}$ glycyl glycine, $15 \mathrm{mM}$ $\mathrm{MgSO}_{4}, 4$ mM EGTA, $100 \mathrm{mM}$ potassium phosphate, $200 \mathrm{mM}$ ATP, $1 \mathrm{M}$ DTT) with $1 \mathrm{M}$ D-luciferin (Life Technologies, Inc. Carlsbad, CA) was quantified. Luciferin substrate was injected followed by $12 \mathrm{~s}$ read by a POLARstar OPTIMA (BMG LabTech, Offenburg, Germany). The results are presented as the average fold induction of treated over untreated cells (DMSO) after correcting for transfection efficiency from triplicate experiments. Dose response curves were fitted to Gaussian distribution on prism with the equation, $\mathrm{Y}=$ Amplitude $* \exp \left(-0.5^{*}((\mathrm{X}-\mathrm{Mean}) / \mathrm{SD})^{\wedge} 2\right)$.

\section{Progesterone receptor competitive binding assay}

The progesterone receptor competitive binding assay kit was purchased from (Life Technologies, Inc. Carlsbad, CA). The progesterone receptor ligand binding domain (amino acids 675-933) fused to GST (PR-LBD-GST; $80 \mathrm{nM}$ ), a fluorescently tagged PR ligand (fluoromone green PL; $4 \mathrm{nM}$ ), and either progesterone (1 nM), plant extracts, or compounds were incubated in PR screening buffer with $4 \mathrm{mM}$ dithiothreitol (DTT) in a total volume of $100 \mu \mathrm{L}$ for $1 \mathrm{~h}$ at room temperature as described previously [24]. Each sample was analyzed in triplicate using POLARstar OPTIMA (BMG LabTech, Offenburg, Germany). An average of three samples containing only buffer and PR-LBD-GST with no fluorescent PL was used as the blank to eliminate background signal from the protein or buffer. A sample with no competitor was used to determine $100 \%$ binding capacity of the PR-LBD-GST for the PL ligand.

\section{Cytotoxicity assay}

The sulforhodamine B (SRB) assay was used to measure cell viability. Cells were plated at 1,000 cells per well in a 96-well plate and treated with DMSO or compounds for $24 \mathrm{~h}$. To process the plates, $50 \mu \mathrm{L}$ of cold $50 \%$ trichloroacetic acid (TCA) was added to the media (final concentration 20\%) and stored at $4{ }^{\circ} \mathrm{C}$ for $30 \mathrm{~min}$. The plates were washed with water and dried overnight. The following day the plates were stained with $100 \mu \mathrm{L}$ of sulforhodamine B (SRB) at room temperature, washed with $1 \%(\mathrm{v} / \mathrm{v})$ acetic acid and dried in the dark overnight. The dye was resuspended in $200 \mu \mathrm{L} 0.1 \mathrm{mM}$ Tris buffer and agitated until the dye was completely solubilized. The plates were read using the endpoint mode at $515 \mathrm{~nm}$. Calculation of the percent cytotoxicity was determined using equation [1$\left.\left(\left(\mathrm{OD}_{\text {sample }}-\mathrm{OD}_{\text {day } 0}\right) /\left(\mathrm{OD}_{\mathrm{DMSO}}-\mathrm{OD}_{\text {day } 0}\right)\right)\right] \times 100=\%$ cell death.

\section{Quantitative PCR}

Quantitative PCR was used to examine the modulation of zinc finger and BTB domaincontaining protein 16 (ZBTB16), prolactin (PRL) and cannabinoid receptor 1 (CNR1) by phytoprogestins in T47D cells or HESC using SYBR green fluorescence. To demonstrate feasibility, RNA was extracted using Qiagen RNeasy Mini Kit (Qiagen, Valencia, CA) and reverse transcribed using RevertAid first strand cDNA synthesis kit (Fermentes, Glen Burnie, MD) according the manufacturers' protocols. Each reaction consisted of $100 \mathrm{ng}$ cDNA, $10 \mu \mathrm{L}$ SYBR Green PCR Master Mix (PE Applied Biosystems, Carlsbad, CA), and $0.5 \mu \mathrm{M}$ forward and reverse primers (Sigma, St. Louis, MO) for 40 cycles $\left(95^{\circ} \mathrm{c}\right.$ for $15 \mathrm{~s}, 65$ ${ }^{\circ} \mathrm{C}$ for $1 \mathrm{~min}$ ) (Supplemental Table 2). The fold changes in all genes were analyzed with the $\Delta \triangle \mathrm{Ct}$ method, with GAPDH or H3F3 as an internal control. Data reported are the mean fold change \pm SEM for three replicates over negative control DMSO.

\section{Western Blot Analysis}

T47D cells were incubated in serum free media with DMSO or compounds for $1.5 \mathrm{~h}$ or $24 \mathrm{~h}$. Cells were lysed in 1X RIPA buffer (50 mM Tris, pH 7.6, $150 \mathrm{mM} \mathrm{NaCl}, 1 \%$ (v/v) Triton 
X-100, 0.1\% (w/v) SDS) and Roche protease inhibitor (Roche, Madison, WI). Protein concentrations were measured using BCA protein assay reagent (Fisher, Rockford, IL). Protein was separated on denaturing 7\% SDS-PAGE gels and transferred to PVDF membranes using iBlot (Life Technologies, Inc. Carlsbad, CA). Membranes were blocked in $3 \%$ milk in Tris buffered saline-Tween ( $1 \mathrm{M} \mathrm{NaCl}, 2 \% 1 \mathrm{M}$ Tris, 3\% Tween 20). Membranes were probed overnight at $4^{\circ} \mathrm{C}$ with antibody against PR-A/B (Cell Signaling, Danvers, MA) at a dilution of 1:500 in 3\% milk in TBS-T. Membranes were washed and probed with HRP-linked secondary antibody (Cell Signaling, Danvers, MA).

Chemiluminescent was detected using SuperSignal West Femto Chemiluminescent Kit, (Thermo Scientific, Hanover Park, IL) according to the manufacturer's protocol and imaged on a Syngene G:Box P20111247 (Imgen Technologies, Alexandria, VA). Membranes were reblotted for actin (Cell Signaling, Danvers, MA) as loading control. Densitometry analysis was performed using Image-J from NIH and the average fold change from three blots is reported.

\section{Results}

\section{Plant extracts bound to PR and induced PRE-luciferase in T47D breast epithelial cells}

Eight ethanolic botanical preparations commonly used for women's health were tested for their ability to interact with purified progesterone receptor (PR) and for induction of a progesterone responsive element (PRE) linked to luciferase in T47D breast cancer epithelial cells (Table 1). The T47D cell line was used due to its high endogenous expression of PR [18]. Four plant extracts demonstrated a significant dose-dependent ability to interact with purified PR in a receptor binding assay: the $75 \% \mathrm{EtOH}$ extracts of valerian, dong quai, dogwood, and red clover (Table 1). The 75\% EtOH extracts of hops and kudzu could not be measured for receptor binding due to interference of the crude plant extract with changes in fluorescence polarization. To determine if botanical extracts induce expression of a progesterone reporter gene, T47D cells were transiently cotransfected with the PREluciferase plasmid and used to measure activation of the functional PR-PRE complex in response to treatment with botanical extracts. Only red clover $(20 \mu \mathrm{g} / \mathrm{ml})$ significantly activated PRE-luciferase induction (Table 1). The hops extract was cytotoxic in T47D cells and could not be evaluated in this assay (Table 1). Dogwood bound to the PR but did not induce PRE-luciferase activity (Table 1). Therefore, extracts were incubated with progesterone to determine if they bound the receptor and functioned as antagonists. In the presence of $100 \mathrm{nM} \mathrm{P}_{4}$, only dogwood and black cohosh extracts significantly inhibited $\mathrm{P}_{4}$ induced activation of luciferase in T47D cells indicating that they function as receptor antagonists (Figure 1).

\section{Identification of pure compounds from botanicals with progestegenic activity that dose dependently bound to PR, induced PRE-luciferase and are inhibited by the PR antagonist RU486 in T47D cells}

Since a 75\% ethanolic extract of red clover significantly induced PRE-luciferase activity (Table 1), a library of 26 compounds (Supplemental Table 1) previously isolated from red clover [19] were tested for their ability to bind to PR and activate the PRE-luciferase reporter gene (Table 2). Genistein, daidzein, biochanin A, and formononetin are isoflavonoids from red clover that were previously reported to interact with and activate estrogen receptor (ER) signaling [20]. First, the isoflavones with estrogenic activity were investigated to confirm that these compounds could not also interact with and activate PR. None of the isoflavones with estrogenic activity significantly interacted with purified PR in a receptor binding assay or induced PRE-luciferase expression. From the library, kaempferol was identified from red clover as a ligand for PR. Apigenin was investigated based on its similar structure to kaempferol and is a known constituent of chaste-tree berry [21]. Both 
flavonoids were determined to significantly activate PRE-luciferase expression and bind to purified progesterone receptors (Table 2). Naringenin, also found in the red clover library, bound to PR, but did not significantly activate PRE-luciferase at $10 \mu \mathrm{M}$ (Table 2). In order to determine if kaempferol, apigenin, and naringenin could activate PRE-luciferase in a dose-dependent manner, five increasing doses of compounds were tested in T47D cells. $\mathrm{P}_{4}$, kaempferol, apigenin and naringenin all dose-dependently activated PRE-luciferase (Figure 2). Naringenin at $10 \mu \mathrm{M}$ was not significantly different than solvent control (Table 1), but at $20 \mu \mathrm{M}$ reached significance. Based on dose response curves, kaempferol was the most active at $7.5 \mu \mathrm{M}$ (Figure $2 \mathrm{~B}$ ) followed by apigenin at $5 \mu \mathrm{M}$ (Figure $2 \mathrm{C}$ ). To further confirm if these transcriptional effects were PR mediated, cells were treated with and without RU486, a well-characterized PR antagonist. RU486 was able to significantly abrogate $\mathrm{P}_{4}$, kaempferol, apigenin and naringenin-induced PRE-luciferase activity (Figure 2). 100nM $\mathrm{P}_{4}$ induces a 54 fold change over basal. MPA demonstrated comparable activity (data not shown).

\section{Kaempferol, apigenin, and naringenin induced the $\mathrm{P}_{4}$-regulated gene ZBTB16 in T47D breast epithelial cells}

To further evaluate the effects of kaempferol, apigenin, and naringenin on progesterone signaling in breast epithelial cells, induction of the $\mathrm{P}_{4}$ responsive gene ZBTB16 was measured using SYBR green real-time PCR (Figure 3) [22]. Kaempferol (100 $\mu$ M) significantly induced ZBTB16 mRNA after $24 \mathrm{~h}$, while apigenin and naringenin did not induce ZBTB16 at this concentration (Figure 3). However, when cells were treated at higher doses of the purified compounds $(250 \mu \mathrm{M})$, the induction of ZBTB16 was significant for all three flavonoids (Figure 3). The presence of the PR antagonist, RU486, significantly inhibited $\mathrm{P}_{4}$ or phytoprogestin-induced ZBTB16 expression (Figure 3). The positive control $(100 \mathrm{nM})$ was much more potent compared to phytoprogestins even when used at higher concentrations $(100 \mu \mathrm{M}$ and $250 \mu \mathrm{M})$.

\section{Kaempferol, apigenin, and naringenin dose-dependently induced PRE-luciferase in human endometrial stromal cells (HESC) that is antagonized by RU486}

The cell and tissue context is critical when investigating $\mathrm{P}_{4}$ signaling because the actions of $\mathrm{P}_{4}$ can be both tissue and cell type specific [23]. In the uterus, cell type specific signaling is especially important since progesterone blocks estrogen-induced proliferation by acting on the stromal cells, a phenomenon not seen in breast epithelial cells, such as T47D, suggesting that progestins may have differential biological activity and potency in the breast as compared to the uterus [24]. Because $\mathrm{P}_{4}$ signals in the stromal cells of the uterus, the ability of kaempferol, apigenin, and naringenin to induce PRE-luciferase activity at different doses was investigated in a human endometrial stromal cell line (HESC) (Figure 4A).

Medroxyprogesterone acetate (MPA) kaempferol, and apigenin, but not naringenin, dosedependently activated PRE-luciferase in HSEC (Figure 4a). MPA was the most active compound followed by kaempferol and apigenin (Figure 4A). However, at higher concentrations, kaempferol and MPA had similar potency (Figure 4A). Purified compounds at $20 \mu \mathrm{M}$ significantly upregulated PRE-luciferase expression in HESC and the presence of $1 \mu \mathrm{M}$ RU486 significantly inhibited MPA, kaempferol, and apigenin induced PREluciferase at $20 \mu \mathrm{M}$ (Figure 4A). In HESC cells, the positive control and kaempferol had similar biological activities indicating that purified compounds exert more potent transcriptional activity in HESC compared to T47D cells.

\section{Kaempferol, apigenin, and naringenin induced decidualization genes, PRL and CNR1, in HESC human endometrial stromal cells}

Decidualization is the morphological and biochemical change of the endometrial stroma during embryonic implantation, a process that critically relies on the end point of $\mathrm{P}_{4}$ 
signaling. During this process, new proteins such as prolactin (PRL) and cannabinoid receptor 1 (CNR1) are expressed due to progesterone signaling [25]. To evaluate the ability of kaempferol, apigenin, and naringenin to induce endogenous progesterone signaling in endometrial stromal cells, genes activated during decidualization were measured using SYBR green quantitative PCR. In contrast to T47D cells, $100 \mu \mathrm{M}$ kaempferol, apigenin and naringenin induced PRL expression in HESC cells after $48 \mathrm{~h}$ (Figure 5A). The induction of decidualization genes was attenuated in the presence of $1 \mu \mathrm{M}$ RU486 (Figure 5A). A similar trend was observed when CNR1 expression was measured, with the exception of naringenin, which did not induce CNR1 expression (Figure 5B).

\section{Kaempferol, apigenin, and naringenin did not downregulate PRA or PRB expression in T47D breast epithelial cells}

Progestin agonists autoregulate PR gene expression via a negative feedback loop [26]. Proteasomal downregulation stimulated by $\mathrm{P}_{4}$ binding of PR could be partially responsible for the progestin therapy resistance seen in endometriotic patients [27]. If phytoprogestins can activate progesterone signaling without simultaneously downregulating PR, then an alternative therapeutic approach could be attempted using these natural ligands. The regulation of PRA and PRB expression by kaempferol, apigenin, and naringenin in breast epithelial cells was analyzed by western blot analysis. Cells exposed to $1 \mu \mathrm{M} \mathrm{P}_{4}$ for $1.5 \mathrm{~h}$ (Figure 6A) or $16 \mathrm{~h}$ (Figure 6B) exhibited downregulation of PRB and more noticeably PRA, which was not observed with $100 \mu \mathrm{M}$ kaempferol, apigenin, and naringenin treatments.

\section{Kaempferol and apigenin antagonized $P_{4}$-induced PRE-luciferase activity in T47D breast epithelial cells}

Analyses of phytoestrogens like genistein have demonstrated their biphasic behavior, acting as agonists when no other hormone is present but functioning as antagonists in the presence of more potent estrogens such as estradiol. In addition, apigenin was recently reported to prevent MPA-induced mammary tumors in rats, suggesting that apigenin is a weak agonist in the presence of the more potent progestin, MPA [28]. To investigate if purified compounds can elicit similar functions in vitro, T47D cells were incubated in combination with $100 \mathrm{nM} \mathrm{P}_{4}$ plus $10 \mu \mathrm{M}$ kaempferol, apigenin, or naringenin for $24 \mathrm{~h}$. Kaempferol and apigenin, but not naringenin, significantly downregulated $\mathrm{P}_{4}$-induced PRE-luciferase (Figure 7).

\section{Discussion}

In this study, the progestegenic activity of eight commonly used botanicals for women's health and a library of purified compounds from red clover were evaluated using several in vitro progestegenic assays. Despite equivocal results in several double-blinded placebo controlled clinical trials evaluating botanicals as alternative therapies for the alleviation of hot flashes, women continue to utilize botanicals, emphasizing the importance of continued research into their safety and biological mechanism(s) of action [29]. Published literature demonstrate that red clover contains estrogenic compounds, which explains its therapeutic use for the alleviation of menopausal symptoms [20], but the unknown presence of progestins in the crude extract might improve its safety in terms of uterine cell proliferation. The competitive binding of purified PR, induction of transiently transfected PRE-luciferase, and the up-regulation of $\mathrm{P}_{4}$ inducible genes, in both T47D breast cancer epithelial and HESC cell lines suggests that an ethanolic extract of red clover contains natural ligands that can activate signaling through PR. The experimental results from this study show that natural progestins kaempferol and naringenin were identified from a library of compounds isolated from red clover. Apigenin, a structurally similar flavonoids, demonstrated similar 
progesterone-like biological activity to naringenin and kaempferol. Progestegenic and estrogenic components found together in red clover may provide the benefits of estrogen for mitigating menopausal symptoms and the progestins necessary to combat the formation of estrogen-induced uterine cancers.

In the current study, the pure compounds identified in red clover (kaempferol, naringenin) and a structurally related flavonoid from chaste-tree berry (apigenin) bound to the PR and activated canonical and endogenous $\mathrm{P}_{4}$ signaling in breast epithelial T47D and uterine stromal cells. These "phytoprogestins" showed considerably lower progestegenic activity compared to positive control $\mathrm{P}_{4}$, suggesting that they are weak PR agonists in the breast epithelial cells (Phytoprogestins are more than 50 fold weaker than $\mathrm{P}_{4}$ ). The disparity in doses used between the in vitro binding and the cell based transcription assays could reflect the more complex cell based environment, specifically the ability or inability to cross the cell membrane, the importance of transcription factor comodulators, or interaction with other protein targets in the cell. Due to the sensitivity of transfected cells, the treatment concentrations in the luciferase reporter assays had to be maintained at doses lower than 20 $\mu \mathrm{M}$. As seen with apigenin and kaempferol, the activity of PRE-luciferase started to decrease at concentrations higher than $5 \mu \mathrm{M}$ and $10 \mu \mathrm{M}$ likely due to cell death. Gene induction experiments allowed for higher treatment concentrations $(100 \mu \mathrm{M}, 250 \mu \mathrm{M})$ since these cells were not subjected to transfection prior to treatment. Interestingly, when PREluciferase reporter assay and gene induction experiments were repeated in the endometrial stromal cells, phytoprogestins demonstrated higher progestegenic potency in relation to MPA, which was used in lieu of P4 based on existing literature [25, 27, 30-33]. The discrepancies between the two cell types indicate that phytoprogestins may have the potential to confer the beneficial effects of progestins in the uterus while avoiding their drawbacks in the breast by functioning like a natural SPRM (selective progesterone receptor modulator). The molecular basis responsible for cell selectivity of phytoprogestins could be in part due to the different expression levels of coactivator and corepressor proteins found in the breast epithelial and endometrial stromal cells [11], subsequently regulating transcription of downstream gene targets. In addition, the expression ratios of the two PR isoforms (PRA, PRB) vary in reproductive tissues depending on the cell type [3], therefore, phytoprogestins may differentially mediate their effects depending on the tissue or cell target. Although the overall total level of PR is higher in T47D, the ligands were more active in HESC cells demonstrating that additional factors beyond receptor binding impact transcription. Zhao et. al [30] showed that the PR concentration in the endometrial stromal cells was only $10 \%$ of that detected in T47D breast epithelial cells, whereby PRB is the dominant isoform. Phytoprogestins were able to activate P4 signaling in T47D cells without downregulating PR expression, suggesting that these natural ligands could be used to overcome progestin therapy resistance. However the lack of PR degradation by these phytoprogestins could also be attributed to their low $\mathrm{P}_{4}$ activity in this cell line. Unfortunately, low PR expression levels in the endometrial stromal cells due to the lack of prior estradiol priming stifled the investigation of phytoprogestin regulation of PR by western blotting expression in this cell type.

Zand et. al provided the first evidence that apigenin and naringenin may have progestegenic activity [34]. Kaempferol was not investigated in these experiments. In previous reports, only breast cancer cell lines were used to study flavonoids, which does not account for cell type specific activity [34]. Despite not having been previously characterized as active ligands for the PR in vivo, Stroheker et. Al [35] demonstrated that kaempferol and apigenin are not estrogenic. Several pieces of data in the literature further support the idea that kaempferol and apigenin are biologically active as progestins in vivo. For example, Hyder et. al $[28,36]$ recently showed that apigenin prevents the development of MPA-induced mammary tumors in rats. Our in vitro results are consistent with these conclusions based on 
the observations that apigenin and kaempferol acted as weak agonists in breast epithelial cells when no other hormones were present, but in the presence of $\mathrm{P}_{4}$, functioned as antagonists. The antagonistic effect induced by kaempferol and apigenin in the presence of $\mathrm{P}_{4}$ may be explained by its binding to the $\mathrm{PR}$ followed by heterodimerization with $\mathrm{P}_{4}$ - bound PR. The heterodimers could be less effective at binding to the response element of the target genes, leading to silencing of PRE-luciferase gene transcription. Nonetheless, further evaluations of phytoprogestins are necessary to explore its chemopreventive properties against breast cancers that develop in response to progestins such as MPA used in hormone replacement therapy.

Kaempferol inhibits the activation of nuclear factor- $\mathrm{kB}(\mathrm{NF}-\mathrm{\kappa B})$, implicating its potential as an anti-inflammatory agent $[37,38]$. Interestingly, steroids such as progestins can also signal through the PR to elicit similar anti-inflammatory mechanisms by forming a transcriptionally inactive complex between $\mathrm{P}_{4}$-bound PR with NF- $\kappa B$ in the cytoplasm, blocking downstream NF- $\kappa \mathrm{B}$ signaling [39]. Furthermore, studies have shown that kaempferol or $\mathrm{P}_{4}$ can repress lipopolysaccharide (LPS)-induced interleukin-8 (IL-8) and cyclooxygenase 2 (COX-2) expression [38, 40]. In a different study, kaempferol inhibited ovarian cancer tumorigenesis and angiogenesis in an animal model [41, 42] and in human observational studies, kaempferol intake was found to significantly decrease $(40 \%)$ ovarian cancer incidence, [43]. These published data further support that kaempferol may function as a progestin, especially since progestins are one of the only established chemopreventive agents against the development of ovarian cancer [44]. Although kaempferol was successfully identified as an active compound from a red clover compound library, other undiscovered active compounds might be present in the extract, which remains to be explored.

The notion that natural progestins can be identified illustrates a new type of "endocrine disruptor" that could interact with and modify endocrine systems. Endocrine disruption is a critical issue because women are already consuming plant-based therapies for a variety of conditions, such as infertility, breast enlargement, menopausal, and premenstrual symptoms $[45,46]$. Studying the effects and mechanisms of these phytoprogestins will help identify if progesterone signaling is being altered and whether this might contribute to the safety profile of botanical supplements. Promiscuous binding of MPA to GR or AR initiates many side effects [47]. Therefore, defining phytoprogestin binding to alternative biological targets is an important future goal to avoid known negative side effects associated with existing progestins. The cell and tissue selectivity of these phytoprogestins, and the ability to signal through the PR without reducing the receptor expression suggest that future in vivo studies are warranted to further validate their progestegenic nature in an animal model.

Identification and characterization of natural progesterone-like molecules in plants might allow for informed decisions regarding their use as alternatives to progesterone therapies.

\section{Supplementary Material}

Refer to Web version on PubMed Central for supplementary material.

\section{Acknowledgments}

This work was supported by NIH R21 AT005377-01A1 to (JEB) from the National Center for Complementary and Alternative Medicine (NCCAM) and the Office for Research in Women's Health. This work was supported by the UIC University Graduate Fellowship (MFT). We appreciate the support from the P50 AT00155 UIC/NIH Center for Botanical Dietary Supplements Research sponsored by the Office of Dietary Supplements and the NCCAM for providing the plant materials necessary to complete this study. We are grateful to Dr. Asgerally T. Fasleabas for providing the human endometrial stromal cells and Dr. Ken Korach for the plasmid containing progesterone responsive element (PRE) fused to firefly luciferase. 


\section{References}

1. Scarpin KM, Graham JD, Mote PA, Clarke CL. Progesterone action in human tissues: regulation by progesterone receptor (PR) isoform expression, nuclear positioning and coregulator expression. Nucl Recept Signal. 2009; 7:e009. [PubMed: 20087430]

2. Gronemeyer H, Meyer ME, Bocquel MT, Kastner P, Turcotte B, Chambon P. Progestin receptors: isoforms and antihormone action. J Steroid Biochem Mol Biol. 1991; 40:271-8. [PubMed: 1958531]

3. Aupperlee MD, Haslam SZ. Differential hormonal regulation and function of progesterone receptor isoforms in normal adult mouse mammary gland. Endocrinology. 2007; 148:2290-300. [PubMed: 17317767]

4. Mulac-Jericevic B, Lydon JP, DeMayo FJ, Conneely OM. Defective mammary gland morphogenesis in mice lacking the progesterone receptor B isoform. Proc Natl Acad Sci U S A. 2003; 100:9744-9. [PubMed: 12897242]

5. Peluso JJ, Romak J, Liu X. Progesterone receptor membrane component-1 (PGRMC1) is the mediator of progesterone's antiapoptotic action in spontaneously immortalized granulosa cells as revealed by PGRMC1 small interfering ribonucleic acid treatment and functional analysis of PGRMC1 mutations. Endocrinology. 2008; 149:534-43. [PubMed: 17991724]

6. Vierikko P, Kauppila A, Ronnberg L, Vihko R. Steroidal regulation of endometriosis tissue: lack of induction of 17 beta-hydroxysteroid dehydrogenase activity by progesterone, medroxyprogesterone acetate, or danazol. Fertil Steril. 1985; 43:218-24. [PubMed: 2981748]

7. Soper JT, McCarty KS Jr, Creasman WT, Clarke-Pearson DL, McCarty KS Sr. Induction of cytoplasmic progesterone receptor in human endometrial carcinoma transplanted into nude mice. Am J Obstet Gynecol. 1984; 150:437-9. [PubMed: 6486209]

8. Kuhl H, Stevenson J. The effect of medroxyprogesterone acetate on estrogen-dependent risks and benefits--an attempt to interpret the Women's Health Initiative results. Gynecol Endocrinol. 2006; 22:303-17. [PubMed: 16785155]

9. Mosher WD, Jones J. Use of contraception in the United States: 1982-2008. Vital Health Stat. 2010; 23:1-44.

10. Milsom I, Odlind V. Oral contraceptives give long-lasting protection against ovarian cancer. Use of oral contraceptives can explain reduced incidence of ovarian cancer in Sweden. Lakartidningen. 2008; 105:715-6. [PubMed: 18422235]

11. Chwalisz K, Perez MC, Demanno D, Winkel C, Schubert G, Elger W. Selective progesterone receptor modulator development and use in the treatment of leiomyomata and endometriosis. Endocr Rev. 2005; 26:423-38. [PubMed: 15857972]

12. Liu J, Burdette JE, Xu H, Gu C, van Breemen RB, Bhat KP, et al. Evaluation of estrogenic activity of plant extracts for the potential treatment of menopausal symptoms. J Agric Food Chem. 2001; 49:2472-9. [PubMed: 11368622]

13. Burdette JE, Liu J, Lantvit D, Lim E, Booth N, Bhat KP, et al. Trifolium pratense (red clover) exhibits estrogenic effects in vivo in ovariectomized Sprague-Dawley rats. J Nutr. 2002; 132:2730. [PubMed: 11773503]

14. Overk CR, Guo J, Chadwick LR, Lantvit DD, Minassi A, Appendino G, et al. In vivo estrogenic comparisons of Trifolium pratense (red clover) Humulus lupulus (hops), and the pure compounds isoxanthohumol and 8-prenylnaringenin. Chem Biol Interact. 2008; 176:30-9. [PubMed: 18619951]

15. Chadwick LR, Nikolic D, Burdette JE, Overk CR, Bolton JL, van Breemen RB, et al. Estrogens and congeners from spent hops (Humulus lupulus). J Nat Prod. 2004; 67:2024-32. [PubMed: 15620245]

16. Krikun G, Mor G, Alvero A, Guller S, Schatz F, Sapi E, et al. A novel immortalized human endometrial stromal cell line with normal progestational response. Endocrinology. 2004; 145:2291-6. [PubMed: 14726435]

17. Sukerkar PA, Macrenaris KW, Townsend TR, Ahmed RA, Burdette JE, Meade TJ. Synthesis and biological evaluation of water-soluble progesterone-conjugated probes for magnetic resonance imaging of hormone related cancers. Bioconjug Chem. 2011; 22:2304-16. [PubMed: 21972997] 
18. Nardulli AM, Katzenellenbogen BS. Progesterone receptor regulation in T47D human breast cancer cells: analysis by density labeling of progesterone receptor synthesis and degradation and their modulation by progestin. Endocrinology. 1988; 122:1532-40. [PubMed: 3345726]

19. Booth NL, Overk CR, Yao P, Burdette JE, Nikolic D, Chen SN, et al. The chemical and biologic profile of a red clover (Trifolium pratense L.) phase II clinical extract. J Altern Complement Med. 2006; 12:133-9. [PubMed: 16566672]

20. Overk CR, Yao P, Chadwick LR, Nikolic D, Sun Y, Cuendet MA, et al. Comparison of the in vitro estrogenic activities of compounds from hops (Humulus lupulus) and red clover (Trifolium pratense). J Agric Food Chem. 2005; 53:6246-53. [PubMed: 16076101]

21. Sirait M, Rimpler H, Haensel R. Flavonoids from Vitex agnus castus L. Experientia. 1962; 18:72. [PubMed: 13913428]

22. Afhuppe W, Sommer A, Muller J, Schwede W, Fuhrmann U, Moller C. Global gene expression profiling of progesterone receptor modulators in T47D cells provides a new classification system. J Steroid Biochem Mol Biol. 2009; 113:105-15. [PubMed: 19130882]

23. Mulac-Jericevic B, Conneely OM. Reproductive tissue-selective actions of progesterone receptors. Ernst Schering Res Found Workshop. 2005:19-37. [PubMed: 15704466]

24. Simon L, Spiewak KA, Ekman GC, Kim J, Lydon JP, Bagchi MK, et al. Stromal progesterone receptors mediate induction of Indian Hedgehog (IHH) in uterine epithelium and its downstream targets in uterine stroma. Endocrinology. 2009; 150:3871-6. [PubMed: 19372202]

25. Buzzio OL, Lu Z, Miller CD, Unterman TG, Kim JJ. FOXO1A differentially regulates genes of decidualization. Endocrinology. 2006; 147:3870-6. [PubMed: 16690806]

26. Abdel-Hafiz H, Takimoto GS, Tung L, Horwitz KB. The inhibitory function in human progesterone receptor $\mathrm{N}$ termini binds SUMO-1 protein to regulate autoinhibition and transrepression. J Biol Chem. 2002; 277:33950-6. [PubMed: 12114521]

27. Bulun SE, Cheng YH, Yin P, Imir G, Utsunomiya H, Attar E, et al. Progesterone resistance in endometriosis: link to failure to metabolize estradiol. Mol Cell Endocrinol. 2006; 248:94-103. [PubMed: 16406281]

28. Mafuvadze B, Benakanakere I, Lopez Perez FR, Besch-Williford C, Ellersieck MR, Hyder SM. Apigenin prevents development of medroxyprogesterone acetate-accelerated 7,12dimethylbenz(a)anthracene-induced mammary tumors in Sprague-Dawley rats. Cancer Prev Res (Phila). 2011; 4:1316-24. [PubMed: 21505181]

29. Geller SE, Shulman LP, van Breemen RB, Banuvar S, Zhou Y, Epstein G, et al. Safety and efficacy of black cohosh and red clover for the management of vasomotor symptoms: a randomized controlled trial. Menopause. 2009; 16:1156-66. [PubMed: 19609225]

30. Zhao D, Lebovic DI, Taylor RN. Long-term progestin treatment inhibits RANTES (regulated on activation, normal $\mathrm{T}$ cell expressed and secreted) gene expression in human endometrial stromal cells. J Clin Endocrinol Metab. 2002; 87:2514-9. [PubMed: 12050207]

31. Wang Y, Hanifi-Moghaddam P, Hanekamp EE, Kloosterboer HJ, Franken P, Veldscholte J, et al. Progesterone inhibition of Wnt/beta-catenin signaling in normal endometrium and endometrial cancer. Clin Cancer Res. 2009; 15:5784-93. [PubMed: 19737954]

32. Brar AK, Frank GR, Kessler CA, Cedars MI, Handwerger S. Progesterone-dependent decidualization of the human endometrium is mediated by cAMP. Endocrine. 1997; 6:301-7. [PubMed: 9368687]

33. Gellersen B, Brosens J. Cyclic AMP and progesterone receptor cross-talk in human endometrium: a decidualizing affair. J Endocrinol. 2003; 178:357-72. [PubMed: 12967329]

34. Zand RS, Jenkins DJ, Diamandis EP. Steroid hormone activity of flavonoids and related compounds. Breast Cancer Res Treat. 2000; 62:35-49. [PubMed: 10989984]

35. Stroheker T, Pinnert MF, Picard K, Chagnon MC, Canivenc-Lavier MC. Estrogenic effects of apigenin, kaempferol and bisphenol A in immature Wistar female rats and in MCF-7 cells. IARC Sci Publ. 2002; 156:413-4. [PubMed: 12489529]

36. Mafuvadze B, Benakanakere I, Hyder SM. Apigenin blocks induction of vascular endothelial growth factor mRNA and protein in progestin-treated human breast cancer cells. Menopause. 2010; 17:1055-63. [PubMed: 20551847] 
37. Hamalainen M, Nieminen R, Vuorela P, Heinonen M, Moilanen E. Anti-inflammatory effects of flavonoids: genistein, kaempferol, quercetin, and daidzein inhibit STAT-1 and NF-kappaB activations, whereas flavone, isorhamnetin, naringenin, and pelargonidin inhibit only NF-kappaB activation along with their inhibitory effect on iNOS expression and NO production in activated macrophages. Mediators Inflamm. 2007; 2007:45673. [PubMed: 18274639]

38. Kim SK, Kim HJ, Choi SE, Park KH, Choi HK, Lee MW. Anti-oxidative and inhibitory activities on nitric oxide (NO) and prostaglandin E2 (COX-2) production of flavonoids from seeds of Prunus tomentosa Thunberg. Arch Pharm Res. 2008; 31:424-8. [PubMed: 18449498]

39. van der Burg B, van der Saag PT. Nuclear factor-kappa-B/steroid hormone receptor interactions as a functional basis of anti-inflammatory action of steroids in reproductive organs. Mol Hum Reprod. 1996; 2:433-8. [PubMed: 9238713]

40. Loudon JA, Elliott CL, Hills F, Bennett PR. Progesterone represses interleukin-8 and cyclooxygenase-2 in human lower segment fibroblast cells and amnion epithelial cells. Biol Reprod. 2003; 69:331-7. [PubMed: 12672669]

41. Luo H, Jiang BH, King SM, Chen YC. Inhibition of cell growth and VEGF expression in ovarian cancer cells by flavonoids. Nutr Cancer. 2008; 60:800-9. [PubMed: 19005980]

42. McCann SE, Freudenheim JL, Marshall JR, Graham S. Risk of human ovarian cancer is related to dietary intake of selected nutrients, phytochemicals and food groups. J Nutr. 2003; 133:1937-42. [PubMed: 12771342]

43. Gates MA, Tworoger SS, Hecht JL, De Vivo I, Rosner B, Hankinson SE. A prospective study of dietary flavonoid intake and incidence of epithelial ovarian cancer. Int J Cancer. 2007; 121:222532. [PubMed: 17471564]

44. Terry KL, De Vivo I, Titus-Ernstoff L, Sluss PM, Cramer DW. Genetic variation in the progesterone receptor gene and ovarian cancer risk. Am J Epidemiol. 2005; 161:442-51. [PubMed: 15718480]

45. Gunther S, Patterson RE, Kristal AR, Stratton KL, White E. Demographic and health-related correlates of herbal and specialty supplement use. J Am Diet Assoc. 2004; 104:27-34. [PubMed: 14702580]

46. Kelly JP, Kaufman DW, Kelley K, Rosenberg L, Anderson TE, Mitchell AA. Recent trends in use of herbal and other natural products. Arch Intern Med. 2005; 165:281-6. [PubMed: 15710790]

47. de Voogt HJ, Smith PH, Pavone-Macaluso M, de Pauw M, Suciu S. Cardiovascular side effects of diethylstilbestrol, cyproterone acetate, medroxyprogesterone acetate and estramustine phosphate used for the treatment of advanced prostatic cancer: results from European Organization for Research on Treatment of Cancer trials 30761 and 30762. J Urol. 1986; 135:303-7. [PubMed: 2935644] 


\section{Highlights}

1. A red clover extract activated a progesterone reporter gene.

2. A red clover extract bound to purified progesterone receptors.

3. A library of pure compounds identified kaempferol as a PR ligand in red clover

4. Kaempferol and apigenin stimulated PR activation in breast and uterine cells. 


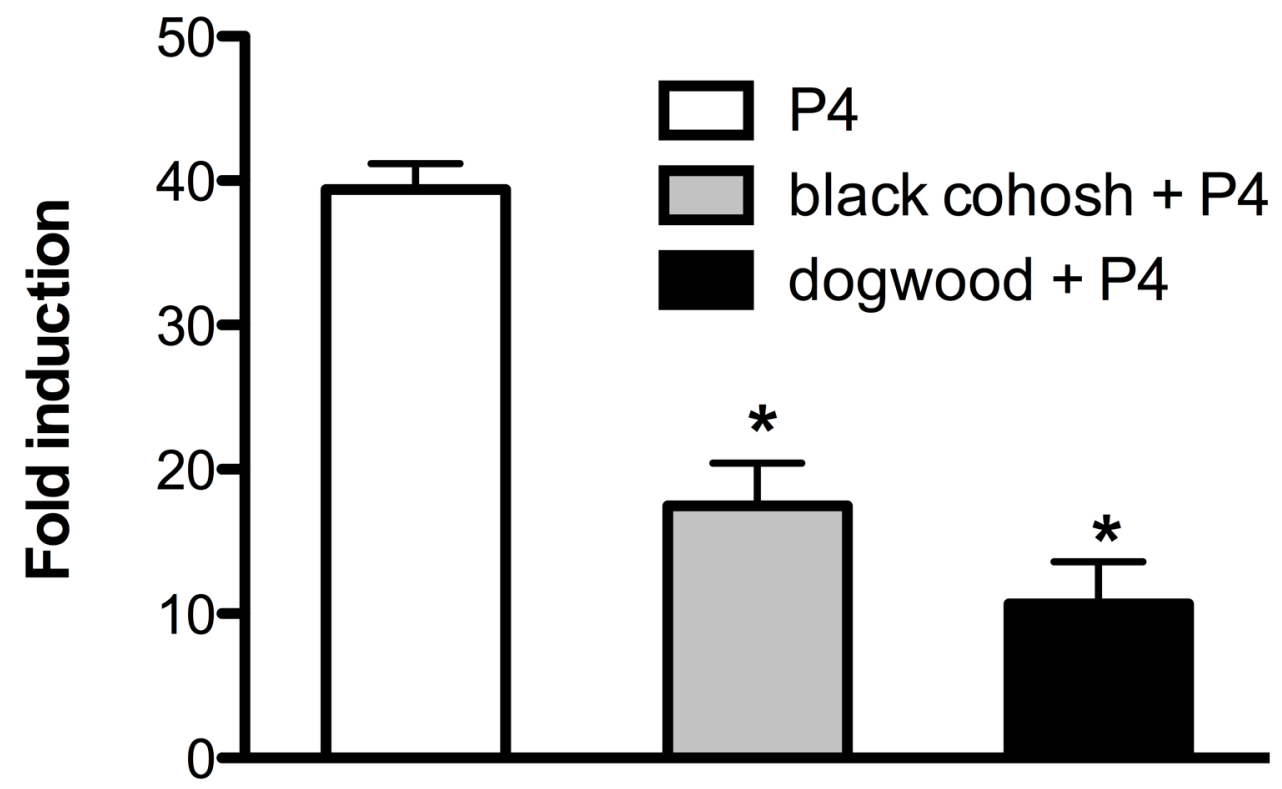

Figure 1.

Botanicals that bind to and do not activate PRE-luciferase function as antagonists when combined with progesterone (P4). PRE-luciferase expression in T47D cells treated with P4 $(1 \mu \mathrm{M})$ and black cohosh or dogwood $(20 \mu \mathrm{g} / \mathrm{mL})$. Data represent average $+/-$ SEM fold change of relative light units normalized to $\beta$-gal in three independent experiments.

Significant differences from the control DMSO value were determined by t-test. $* \mathrm{p}<0.05$ 

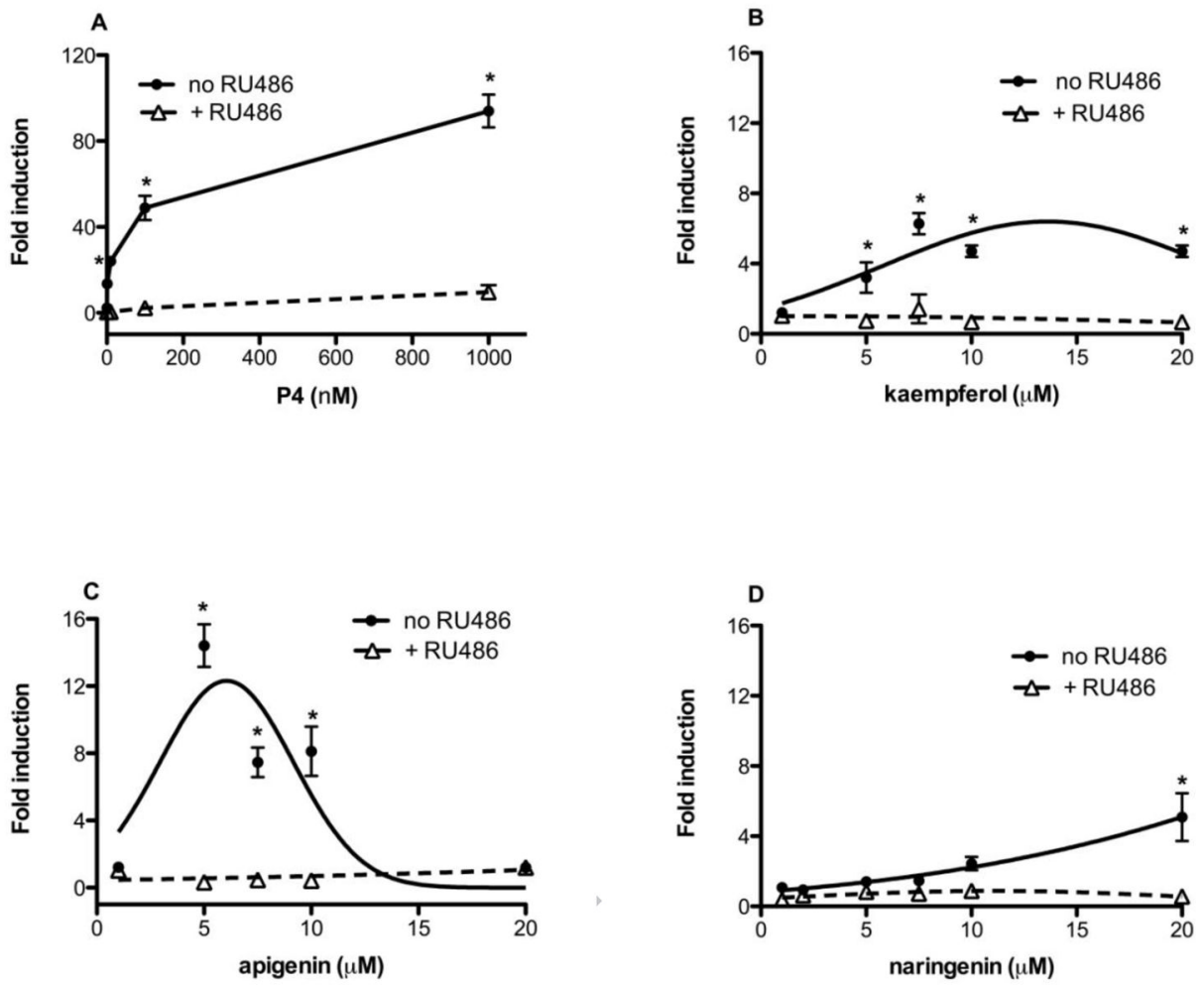

Figure 2.

Kaempferol, apigenin and naringenin, dose-dependently activate PRE-luciferase and can be antagonized by the PR antagonist, RU486. T47D cells were transiently transfected with PRE-luciferase and treated with increasing concentrations of pure compounds with and without PR antagonist ( $1 \mu \mathrm{M}$ RU486). Results are the means of three independent experiments \pm SEM. Significant differences from the control DMSO value were determined by the unpaired two-sample student t-test. ${ }^{*} \mathrm{p}<0.05$. 


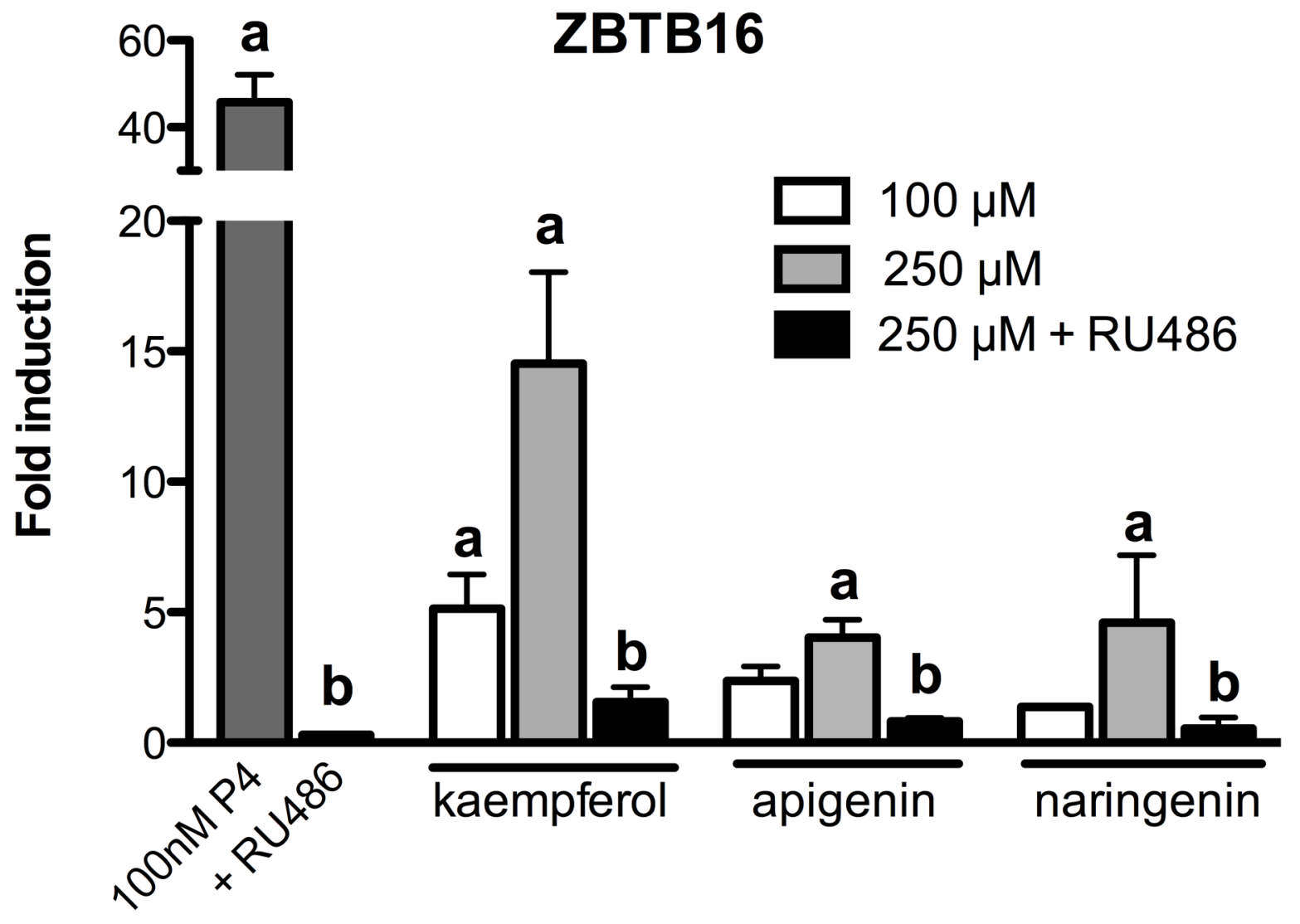

Figure 3.

Expression of ZBTB mRNA in response to kaempferol, apigenin and naringenin in T47D cells. T47D cells were treated with $100 \mu \mathrm{M}$ or $250 \mu \mathrm{M}$ with and without PR antagonist (RU486) for 24 hours. Expression of ZBTB16 was measured using SYBR green real-time PCR. Data are expressed as the average fold change \pm SEM over basal (DMSO) normalized to GAPDH. Data are the mean of three independent experiments. "a" indicates significant induction of ZBTB16 expression compared to basal DMSO; "b" indicates significant downregulation of ZBTB16 expression by $1 \mu \mathrm{M}$ RU486. Significant differences from the control DMSO value or the treatment without antagonist were determined by t-test. ${ }^{*} \mathrm{p}<0.05$. 

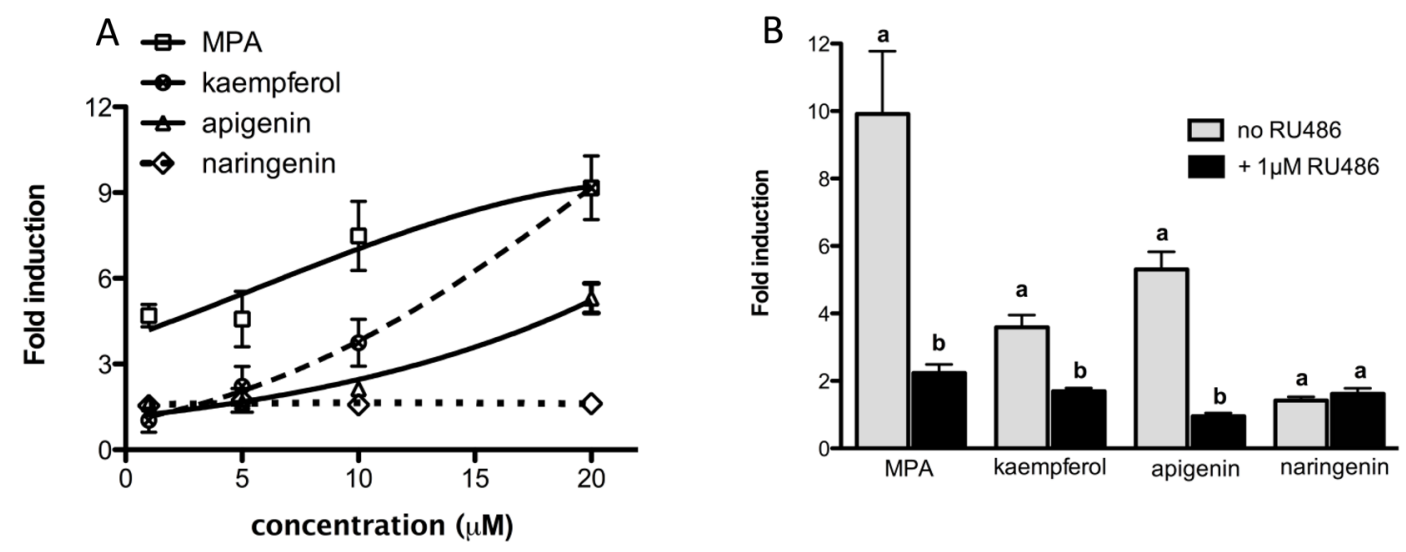

Figure 4.

(A) Kaempferol, apigenin and naringenin, dose-dependently activate PRE-luciferase. Human endometrial stromal cells (HESC) cells were transiently transfected with PREluciferase and treated with increasing concentrations of pure compounds. Results are the means of relative light units normalized to $\beta$-gal in three independent experiments \pm SEM. Significant differences from the control DMSO value were determined by t-test. *p<0.05. (B) Kaempferol, apigenin and naringenin activate PRE-luciferase and can be antagonized by RU486 in human endometrial stromal cells (HESC). HESC were transiently transfected with PRE-luciferase and treated with pure compounds $(20 \mu \mathrm{M})$ with and without PR antagonist (RU486) for 48 hours. Data represent the average of three independent experiments \pm SEM fold change of relative light units normalized to $\beta$-gal in triplicate experiments. "a" indicates significant luciferase induction compared to basal DMSO; "b" indicates significant downregulation of luciferase induction by $1 \mu \mathrm{M}$ RU486. Significant differences from the control DMSO value or the treatment without antagonist were determined by $\mathrm{t}$-test. $* \mathrm{p}<0.05$. 

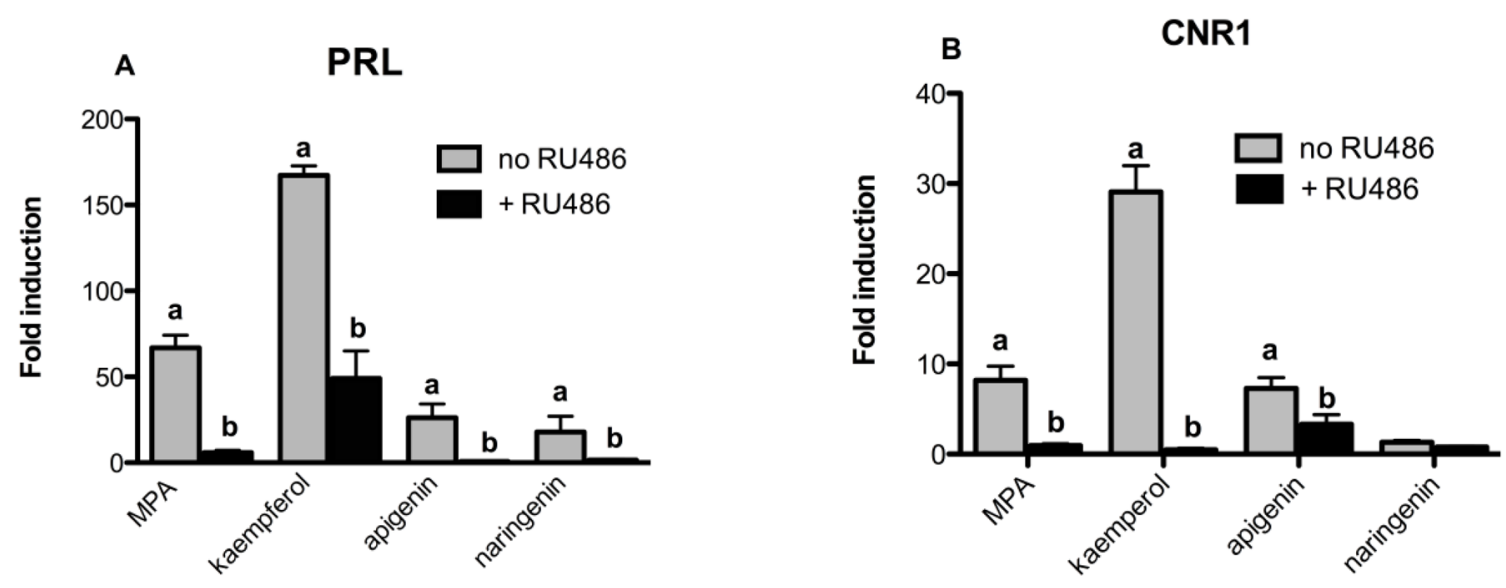

Figure 5.

Expression of decidualization specific mRNA (PRL, CNR1) in response to kaempferol, apigenin and naringenin. Human endometrial stromal cells (HESC) were treated with phytoprogestins $(100 \mu \mathrm{M})$ and MPA $(20 \mu \mathrm{M})$ in the presence of decidualization inducing estrogen (E2) and 8-Br-cAMP, with and without PR antagonist for 48 hours. Expression of decidual genes was measured using SYBR real-time PCR. Data are expressed as the average fold change of three independent experiments \pm SEM over basal (DMSO) normalized to GAPDH or H3F3. "a" indicates significant decidual gene expression compared to basal DMSO; "b" indicates significant downregulation of decidual gene expression by $1 \mu \mathrm{M}$ RU486. Significant differences from the control DMSO value or the treatment without antagonist were determined by t-test. ${ }^{*} \mathrm{p}<0.05$. 
a.

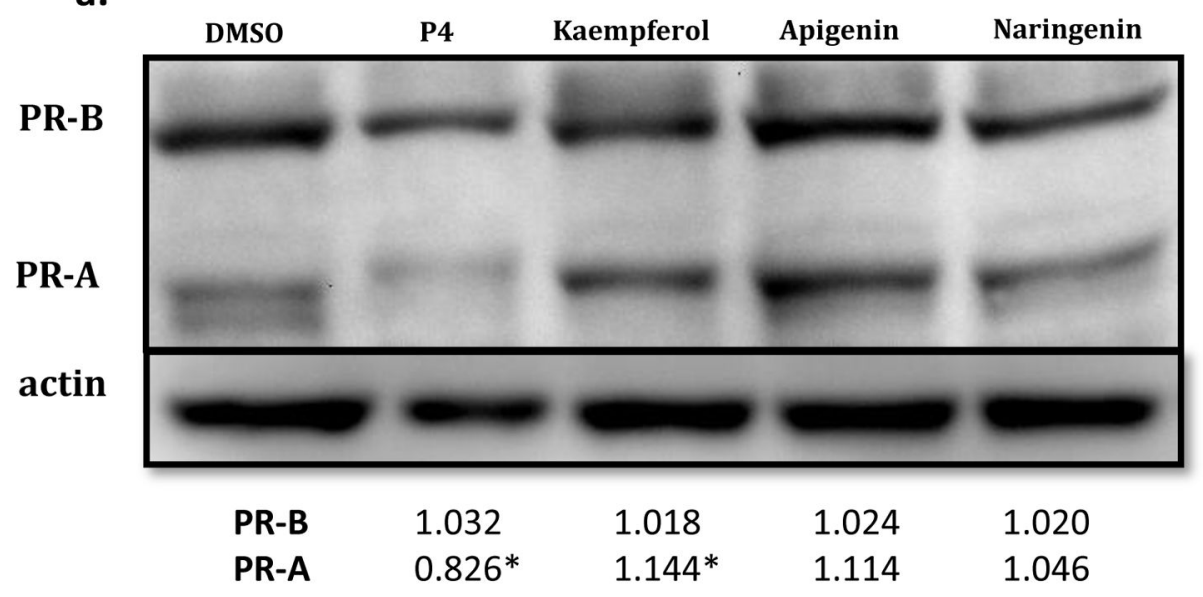

b.

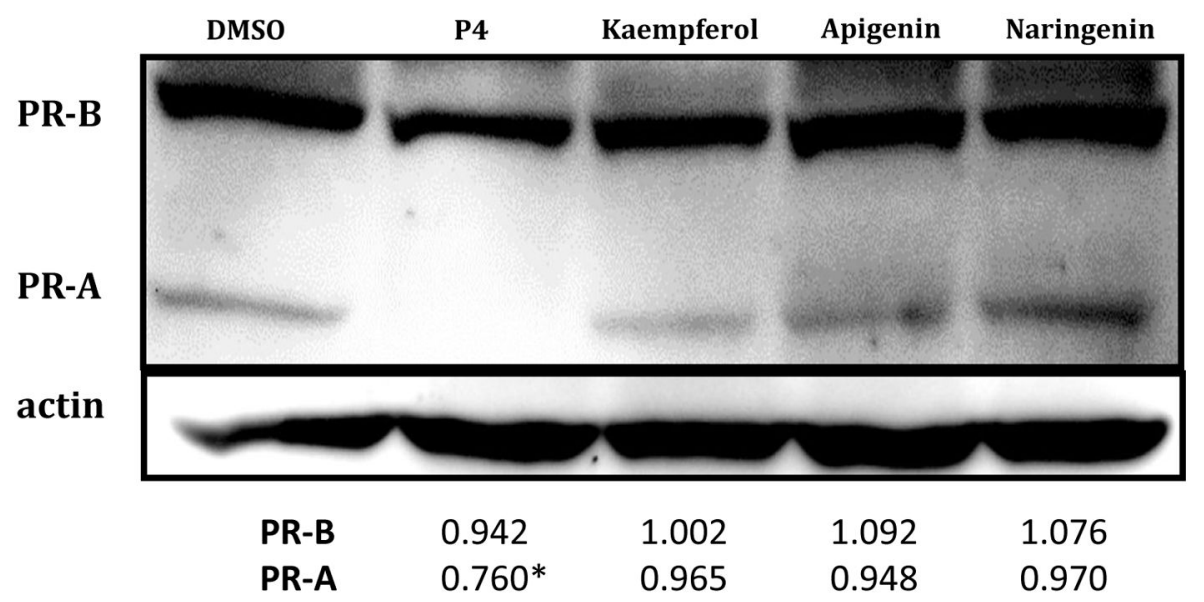

Figure 6.

Progesterone induced downregulation of progesterone receptor in T47D cells. Levels of PRA and PRB protein in T47D cells after treatment $(100 \mu \mathrm{M})$ with kaempferol, apigenin, and naringenin for (a) prior to 1.5 hours, and (b) prior to 16 hours. Membranes were analyzed for actin expression as loading control. PR fold change was analyzed using Image$\mathrm{J}$ in triplicate experiments. $* \mathrm{p}<0.05$ indicates significant fold change of PR compared to basal DMSO. 


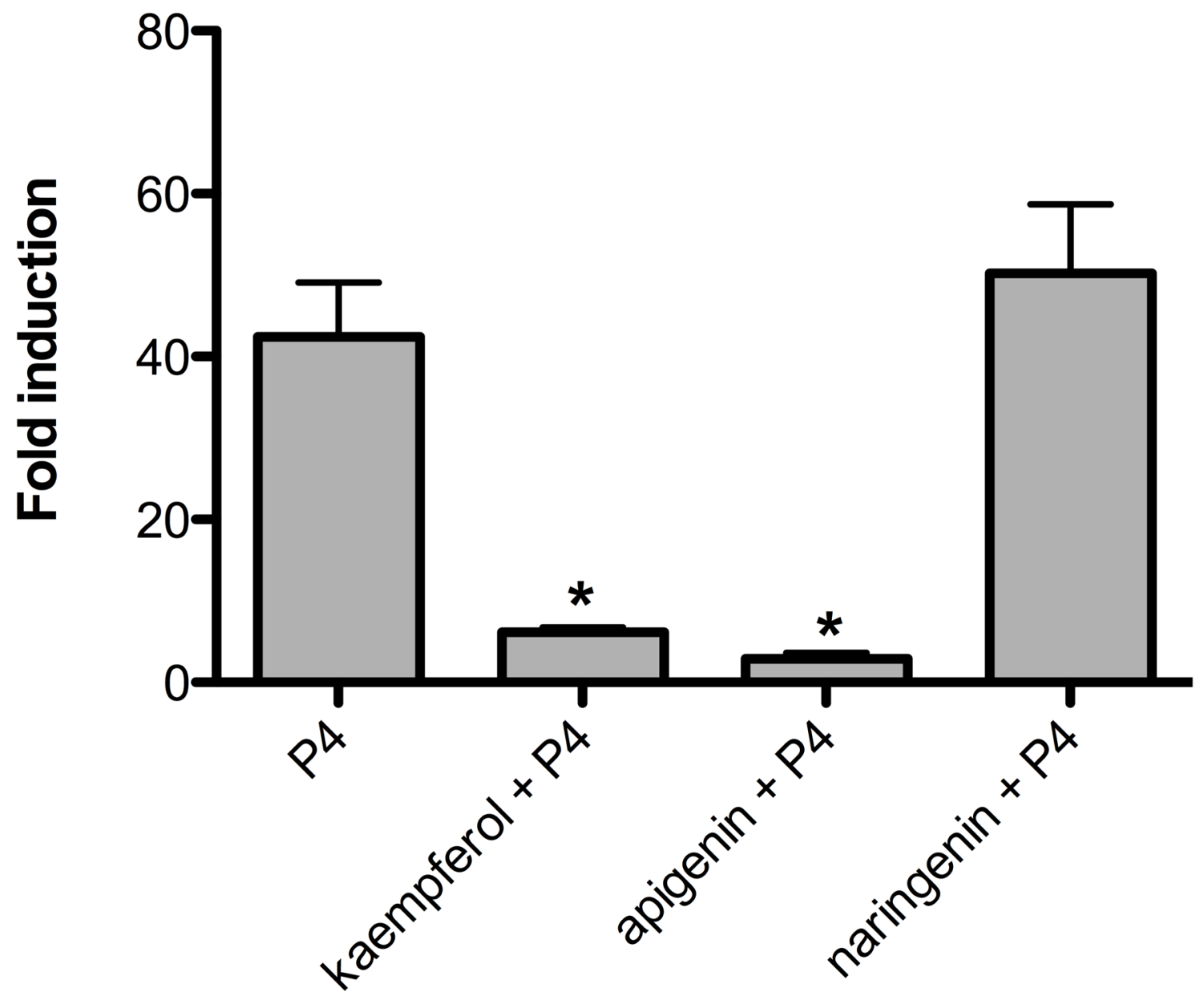

Figure 7.

Purified phytoprogestins are weak PR agonists and function as antagonists when combined with P4 in T47D cells. PRE-luciferase expression in T47D cells treated with P4 (100 nM) and kaempferol, apigenin, and naringenin $(10 \mu \mathrm{M})$. Data represent the mean \pm SEM fold change of relative light units normalized to $\beta$-gal in three independent experiments. ${ }^{*} \mathrm{p}<$ 0.05 indicates significant antagonism of P4 luciferase activity and was determined by t-test. $* \mathrm{p}<0.05$. 


\section{Table 1}

Plant extracts induce PRE-luciferase and bind to PR in T47D breast epithelial cells

Progesterone responsive element (PRE)-luciferase induction, progesterone receptor (PR) binding, and cytotoxicity of plant extracts in human breast cancer epithelial cells (T47D). Botanical extracts $(20 \mu \mathrm{g} / \mathrm{mL})$ were tested at a single concentration in luciferase assays and at five doses in PR binding assays. N/D indicates that the plant extract interferes with measuring polarization. Data represent average \pm SEM fold change of relative light units normalized to $\beta$-gal in three independent experiments. Significant differences from the control DMSO value were determined by t-test.

\begin{tabular}{|l|c|c|c|}
\hline Plant Extracts 75\% Ethanolic $(\mathbf{2 0} \boldsymbol{\mu g} / \mathbf{m L})$ & PRE-luciferase fold increase & ${\text { PR Binding } \mathbf{I C}_{\mathbf{5 0}} \boldsymbol{\mu g} / \mathbf{m L}}$ Toxicity, $\mathbf{T 4 7 D} \mathbf{~ L C} \mathbf{5 0}_{\mathbf{~} \mathbf{g} / \mathbf{m L}}$ \\
\hline Humulus lupulus (Hops) & $2.2 \pm 1.2$ & $\mathrm{~N} / \mathrm{D}$ & 2.5 \\
\hline Cimicifuga racemosa (Black Cohosh) & $1.5 \pm 0.1$ & $>1 \mathrm{mg}$ & $>20$ \\
\hline Cornus officinalis (Dogwood) & $1.3 \pm 1.1$ & $15 \pm 1.4$ & $>20$ \\
\hline Pueraria lobata (Kudzu) & $2.1 \pm 1.4$ & $\mathrm{~N} / \mathrm{D}$ & $>20$ \\
\hline Valeriana officinalis (Valerian) & $1.4 \pm 0.7$ & $97 \pm 17$ & $>20$ \\
\hline Vitex agnus castus (Chaste-Tree Berry) & $1.5 \pm 1.0$ & $>1 \mathrm{mg}$ & $>20$ \\
\hline Angelica sinensis (Dong Quai) & $1.6 \pm 0.7$ & $106 \pm 21$ & $>20$ \\
\hline Trifolium pratense (Red Clover) & $4.7 \pm 1.2^{*}$ & $34 \pm 20$ & $>20$ \\
\hline
\end{tabular}

p $<0.05$. Progesterone has an IC 50 of $25 \mathrm{nM}$ in the PR binding assay and at $100 \mathrm{nM}$ induces a 54 fold change in luciferase activity over basal. 
Table 2

Red clover pure compounds induce PRE-luciferase and bind to PR in T47D breast epithelial cells

PRE-luciferase induction, PR binding, and cytotoxicity of active pure plant-derived estrogenic and progestegenic compounds. Botanical compounds $(10 \mu \mathrm{M})$ were tested for luciferase induction in T47D cells and for binding to the purified PR. Data represent average \pm SEM fold change of relative light units normalized to $\beta$-gal in three independent experiments. Significant differences from the control DMSO value were determined by t-test.

\begin{tabular}{|l|c|c|c|}
\hline Progestegenic Compounds & PRE-luciferase Fold increase $(\mathbf{1 0} \boldsymbol{\mu M})$ & ${\text { PR Binding } \mathbf{I C}_{\mathbf{5 0}} \boldsymbol{\mu M}}^{\text {Toxicity LC }} \mathbf{5 0} \boldsymbol{\mu M}$ \\
\hline Kaempferol & $5.5 \pm 1.8^{*}$ & $1.5 \pm 0.4$ & $>20$ \\
\hline Apigenin & $6.5 \pm 1.9^{*}$ & $1.0 \pm 0.7$ & $>20$ \\
\hline Naringenin & $1.9 \pm 0.4$ & $6.9 \pm 1.8$ & $>20$ \\
\hline
\end{tabular}

\begin{tabular}{|l|c|c|c|}
\hline Estrogenic Compounds & PRE-luciferase Fold increase $(\mathbf{1 0} \boldsymbol{\mu M})$ & PR Binding $\mathbf{I C}_{\mathbf{5 0}} \boldsymbol{\mu M}$ & Toxicity, $\mathbf{L C}_{\mathbf{5 0}} \boldsymbol{\mu M}$ \\
\hline Genistein & $2.2 \pm 1.1$ & $>250$ & $>20$ \\
\hline Daidzein & $1.0 \pm 0.4$ & $>250$ & $>20$ \\
\hline Biochanin A & $1.0 \pm 0.1$ & $>250$ & $>20$ \\
\hline Formononetin & $1.5 \pm 0.6$ & $>250$ & $>20$ \\
\hline
\end{tabular}

p $<0.05$. Positive control progesterone (P4) had a PR binding IC50 of $25 \mathrm{nM}$. P4 (100 nM) induces a 54 fold change over basal. 